\title{
Detection of arsenite-oxidizing bacteria in groundwater with low arsenic concentration in Rayong province, Thailand
}

\author{
Phurinat Pipattanajaroenkul ${ }^{1}$, Prinpida Sonthiphand ${ }^{2}$, Supeerapat Kraidech ${ }^{1}$, Satika Boonkaewwan $^{1}$, and \\ Srilert Chotpantarat ${ }^{3,4,5^{*}}$ \\ ${ }^{1}$ International Programs in Hazardous Substance and Environmental Management, Graduate School, Chulalongkorn University. \\ Center of Excellence on Hazardous Substance Management (HSM), Chulalongkorn University, Thailand \\ ${ }^{2}$ Department of Biology, Faculty of Science, Mahidol University, Thailand \\ ${ }^{3}$ Department of Geology, Faculty of Science, Chulalongkorn University, Thailand \\ ${ }^{4}$ Research Program on Controls of Hazardous Contaminants in Raw Water Resources for Water Scarcity Resilience, Center of \\ Excellence on Hazardous Substance Management (HSM), Chulalongkorn University, Thailand \\ ${ }^{5}$ Research Unit Control of Emerging Micropollutants in Environment, Chulalongkorn University, Thailand
}

\begin{abstract}
As contamination in groundwater has become one of the global problems. It has been reported that million people around the world get adverse effects on their health by direct and indirect As-contaminated groundwater consumption. In groundwater, the most abundant $\mathrm{As}$ species are arsenite $\left(\mathrm{As}^{3+}\right)$ and arsenate $\left(\mathrm{As}^{5+}\right)$. Arsenite is more toxic and mobile than arsenate. Consequently, arsenite oxidation is considered as an important process in groundwater As bioremediation. It has been reported that arsenite-oxidizing bacteria play an important role in reducing As toxicity in contaminated groundwater environment. A functional gene involved in arsenite oxidation is aio $A$ gene. The key objective of this study was to investigate the arsenite-oxidizing bacteria in groundwater with low arsenic concentration in Rayong province, Thailand. The results showed that the arsenite-oxidizing bacteria were detected in groundwater with low arsenic concentration. Phylogenetic analysis revealed that they were closely related to Rhizobium sp., Bradyrhizobiaceae sp., Hydrogenophaga sp., and Stenotrophomonas sp. The knowledge gained from this study will help better understand the distribution of arsenite-oxidizing bacteria in groundwater with low As concentration.
\end{abstract}

\section{Introduction}

Arsenic (As) is considered as toxic metalloids that widely distributes on the earth's surface. It can cause both acute and chronic effects to human health [1]. It has been reported that there are several countries around the world such as Vietnam, China, Taiwan, Mexico, Argentina, India, Bangladesh and Thailand have As contamination in groundwater problems and millions of people get effects from As by the consumption of this As-contaminated groundwater. Due to As toxicity, the World Health Organization has set the standard of As concentration in drinking water to be $<10 \mu \mathrm{g} / \mathrm{l}$. In groundwater, the most abundant As species are arsenite and arsenate. It is found that arsenite has more toxicity and mobility than arsenate [2]. Both geogenic and anthropogenic origins are considered as sources of As in environment. According to the geological information, As can be released to an environment by the weathering of As-bearing rocks such as granite or the oxidation and dissolution of As-bearing minerals for instance, sulfide minerals and oxide minerals. Furthermore, As can be discharged to an environment by human activities such as agriculture, industry and mining operations which can generate high As concentration. [2,3]. There are many techniques which are used to remove As from groundwater for example, physiochemical techniques such as chemical oxidation, coagulation, reverse osmosis and ion-exchange. It has been reported that these techniques are supposed to be very expensive, inefficient, particularly when As concentration in groundwater is very low [4]. In the present, As bioremediation is considered as an alternative choice to treat As contaminated groundwater. It is found that several microorganisms can survive in high As concentration environments by relying on their cellular mechanisms [5]. In oxidizing environments which arsenate is a predominant As specie. Arsenate can be converted to arsenite by the mechanism of arsenatereducing bacteria. Heterotrophic cytoplasmic arsenatereducing bacteria can reduce arsenate to arsenite by using their cytoplasmic arsenate reductase $(\operatorname{arcC})$ and this activity is considered as a detoxification process [6]. Conversely, dissimilatory arsenate reducing bacteria is considered as an arsenate respirer. These microbes enable to transform arsenate to arsenite by their

* Corresponding author: csrilert@gmail.com 
respiration process and gain energy for growth [7]. It has been reported that this mechanism is driven by their respiratory arsenate reductases (arr) [8]. In reducing environments, arsenite is dominant. Arsenite-oxidizing bacteria have an important role in controlling this toxic arsenite [9]. Arsenite is oxidized to arsenate by mechanism of heterotrophic and chemoautotrophic arsenite-oxidizing bacteria by using their specific enzyme called respiratory arsenite oxidase (aio/aox) [10]. The arsenite oxidation of heterotrophic arseniteoxidizing bacteria (HAOs) is considered as a detoxification process because these microbes unable to gain any energy from this activity to produce their cell materials [11]. While chemoautotrophic arsenite oxidizing bacteria (CAOs) are regarded as an arsenite eater. They can conserve energy for growth through their oxidation process [12]. It has been reported that Bordetella sp. strain SPB-24 and Achromobacter xyloxosidans strain SPB-31, could survive in high As contaminated garden soil by their As detoxification process [13]. It has also been reported that Herminiimonas arsenicoxydans strain UPLAs could chemoautotrophically grow in arsenite concentration up to $500 \mathrm{mg} / \mathrm{l}$ [14]. Since several arsenite oxidizing bacteria were found in various rich As concentration environments, the purpose of this study was to investigate the communities of arsenite-oxidizing bacteria in groundwater with low As concentration to better understand their inherent distributions in this natural environment.

\section{Material and methods}

\subsection{Site description and sample collection}

The groundwater sampling point (GW1) located in Muang district, Rayong province, Thailand with the coordinate of $12^{\circ} 44^{\prime} 2^{\prime \prime} \mathrm{N}$ and $101^{\circ} 9^{\prime} 51^{\prime \prime} \mathrm{E}$. This area was considered as a dense residential area. The groundwater samples were collected from the groundwater well in the volume approximately 3 liters and stored on ice during transportation.

\subsection{Geochemical analysis}

Geochemical parameters such as $\mathrm{pH}$, electrical conductivity (EC), oxidation-reduction potential (ORP), dissolved oxygen (DO) and temperature were measured on site. Total organic carbon was analyzed using a total organic carbon analyser (TOC-VCPH). Total As was analyzed using inductively coupled plasma mass spectrometry (ICP-MS) at the Central Laboratory (Thailand) Co., Ltd. Chachoengsao province.

\subsection{DNA extraction}

The genomic DNA was extracted by using the FastDNATM SPIN Kit for Soil and the FastPreo ${ }^{\circledR}$ instrument (MP Biomedicals, Santa Ana, CA). DNA quality was determined by using agarose gel electrophoresis, while DNA quantity was evaluated by using spectrophotometer nanodrop, respectively. Then, extracted DNA was diluted for the final concentration of $5 \mathrm{ng} / \mu \mathrm{l}$ for using as a DNA template in PCR reaction.

\subsection{Polymerase chain reaction (PCR)}

A DNA template was used to amplify an arsenite oxidase gene (aio $A$ gene) by following conditions of the manufacturer protocol of BioLabs (Taq DNA Polymerase with Thermopol ${ }^{\circledR}$ Buffer: M0267S). The primers: Aox BM1-2F ND and Aox BM2-1R ND were used to amplified aio gene [15]. PCR profile was performed as follow: initial denaturation at $95^{\circ} \mathrm{C}$ for 30 seconds followed by 35 cycles of denaturation $95^{\circ} \mathrm{C}$ for 30 seconds, annealing $55^{\circ} \mathrm{C}$ for 30 seconds, extension $68^{\circ} \mathrm{C}$ for 30 seconds, and final extension at $68^{\circ} \mathrm{C}$ for 5 minutes.

\subsection{DNA purification}

DNA purification was performed by following NucleoSpin ${ }^{\circledR}$ Gel and PCR Clean-up [16]. The PCR product was mixed with Buffer NT1 in NucleoSpin ${ }^{\circledR}$ Gel and PCR Clean-up column within $2 \mathrm{ml}$. collection tube, after that the centrifugation was done for 30 seconds at $11,000 \mathrm{x}$ g. Then, $700 \mu 1$. of Buffer NT3 was added, and the centrifugation was performed again at the same condition. After that, the column was put into 1.5 $\mathrm{ml}$. Microcentrifuge-tube. The 30 of Buffer NE was added, then the microcentrifuge tube was centrifuged for 1 minute at $11,000 \mathrm{x} \mathrm{g}$. Then, incubation at room temperature was done for 1 minute. Finally, purified DNA in the microcentrifuge tube was kept for cloning.

\subsection{Clone library}

The pGEM®-T and pGEM®-T Easy Vector Systems' protocol was used as a ligation and transformation guideline. The ligation product was incubated overnight at $4{ }^{\circ} \mathrm{C}$. After that, transformation was conducted by using XL1-blue super competent cells. The heat shocking was performed at $42^{\circ} \mathrm{C}$ for 45 seconds following by incubation in shaker at $37^{\circ} \mathrm{C}$ for 1 hour with shaking at $250 \mathrm{rpm}$. After that, the transformed product was spread on an LB agar plate which contained $100 \mathrm{mg} / \mathrm{ml}$. of Ampicillin, 50mg/ml. of X-gal and $1 \mathrm{mM}$. of IPTG. The incubation was performed overnight at $37^{\circ} \mathrm{C}$. Finally, 20-25 white colonies which contain arsenite oxidase gene were selected for sequencing.

\subsection{DNA sequencing and phylogenic analysis}

The cloning samples were sent to Macrogen company in South Korea for bacterial DNA sequences analysis. The obtained sequences were compared with database of Genbank. After that the neighbor-joining tree was constructed with 1,000 bootstrap tests by using MEGA 7.021 [17]. 


\section{Result and discussion}

\subsection{Geochemical properties of groundwater}

The geochemical properties of groundwater sample could be briefly described. The $\mathrm{pH}$ of the groundwater sample was 7.1, whereas the dissolved oxygen (DO) of the groundwater was unexpectedly high showing 8.90 $\mathrm{mg} / \mathrm{l}$. Total dissolved solid (TDS) and total organic carbon (TOC) were found at $306.56 \mathrm{mg} / \mathrm{l}$ and $5.10 \mathrm{mg} / \mathrm{l}$, respectively. Furthermore, the value of oxidationreduction potential was $182.80 \mathrm{mV}$ and total As concentration in groundwater was $0.64 \mu \mathrm{g} / \mathrm{l}$. From the geochemical properties, it could be described that the groundwater was relatively neutral and moderately oxidizing condition. With this condition, As could be appeared in both arsenite and arsenate species [18]. The TDS was fairly high representing the salinity of groundwater. Moreover, this elevated TDS corresponds to the location of the study area which located near the Gulf of Thailand. The high TDS might result from the influence of saltwater intrusion [19]. A very high DO might be affected from the shallow depth of groundwater level and the continuous utilization by dense population. In the part of As concentration in groundwater, it was still in the range of the standard of $10 \mu \mathrm{g} / \mathrm{l}$, reflecting the high-quality management in protecting the toxic substance releasing to groundwater resources. However, the existence of As and other geochemical physiochemical parameters could be supportive factors for the arsenite-oxidizing bacteria to survive.

\subsection{Detection of arsenite-oxidizing bacteria}

The arsenite-oxidizing bacteria in groundwater with low As concentration was detected by specific primers targeting aioA gene using the polymerase chain reaction (PCR). The size of aioA gene PCR product is 550 base pairs which was verified using an agarose gel electrophoresis. The groundwater sample analyzed in this study showed a positive result. This result implied that arsenite-oxidizing bacteria could be found in the environment which low As concentration [20]. Then this sample was analyzed to find the diversity of arseniteoxidizing bacterial species by performing the clone library. Five (GW1-1, GW1-2, GW1-3, GW1-4 and GW1-5) analyzed sequences were blasted against the Genbank database using the BLASTn program. The results demonstrated that all analyzed sequences showed $76-84 \%$ identity to previously reported arseniteoxidizing bacteria (Table 1).
Table.1 The identification of aio $A$ gene sequences analyzed by the $\mathrm{BLAST}^{\mathrm{n}}$ program.

\begin{tabular}{|c|c|c|}
\hline $\begin{array}{c}\text { Sequence } \\
\text { ID }\end{array}$ & Bacterial species & $\begin{array}{c}\text { Genbank acc. } \\
\text { No. }\end{array}$ \\
\hline GW1-1 & Stenotrophomonas sp. & JQ739209.1 \\
\hline GW1-2 & Hydrogenophaga sp. & KM884951.1 \\
\hline GW1-3 & Rhizobium sp. & KT992344.1 \\
\hline GW1-4 & Stenotrophomonas sp. & JQ739209.1 \\
\hline GW1-5 & Bradyrhizobiaceae sp & AB974343.1 \\
\hline
\end{tabular}

Phylogenetic analysis showed that all arsenite-oxidizing bacteria detected in this study were closely related to $\alpha, \beta$ and $\gamma$-Proteobacteria (Fig 1). The bacterial clone GW1-3 and GW1-5 were closely related to Rhizobium sp. and Bradyrhizobiaceae sp., respectively. These two bactererial species were a member of $\alpha$-Proteobacteria. The bacterial clone GW1-2 was highly similar to Hydrogenophaga sp. which belongs to $\beta$-Proteobacteria. Furthermore, the result also demonstrated that the bacterial clone GW1-1 and GW1-4 were closely related to Stenotrophomonas sp. which were a member of $\gamma$ Proteobacteria (Fig. 1). It has been reported that the closely related bacterial species such as Rhizobium sp., Bradyrhizobiaceae sp., Hydrogenophaga sp. and Stenotrophomonas sp. carried the aioA (aoxB) gene which was considered as a genetic marker of arseniteoxidizing bacteria [15]. Rhizobium sp. NT-26 was found on arsenopyrite rocks in gold mining where As concentration was in a range of 2,000-13,000 $\mu \mathrm{g} / 1$ [21]. This bacteria showed chemolithoautotrophic growth which used arsenite as an electron donor, oxygen as an electron acceptor and carbondioxide or bicarbonate as carbon source [21, 22]. Hydrogenophaga sp. was detected in the shallow groundwater aquifer with various As concentrations (1-763 $\mu \mathrm{g} / \mathrm{l}$.) [23]. In addition, Stenotrophomonas $\mathrm{sp}$. isolated from soil with low As concentration of $8.8 \mathrm{mg} . / \mathrm{kg}$. demonstrated the heterotrophic arsenite-oxidation by using organic substances such as glucose and maltose as a carbon source, but this bacteria cannot gain energy for its growth [24]. This information indicated that arseniteoxidizing bacteria could be found in several environments for example, mineralized area, soil, and groundwater which various As concentrations. Furthermore, all of these bacteria for instance, Rhizobium sp., Bradyrhizobiaceae sp., Hydrogenophaga $\mathrm{sp}$. and Stenotrophomonas sp. could relieve the toxicity of As by transforming to its less toxic form. The knowledge from this study will be useful for better understanding the distribution of arsnite-oxidizing bacteria in groundwater found in low As concentration. The knowledge gain from this study is the first important step which can be built on for further development of As bioremediation. 


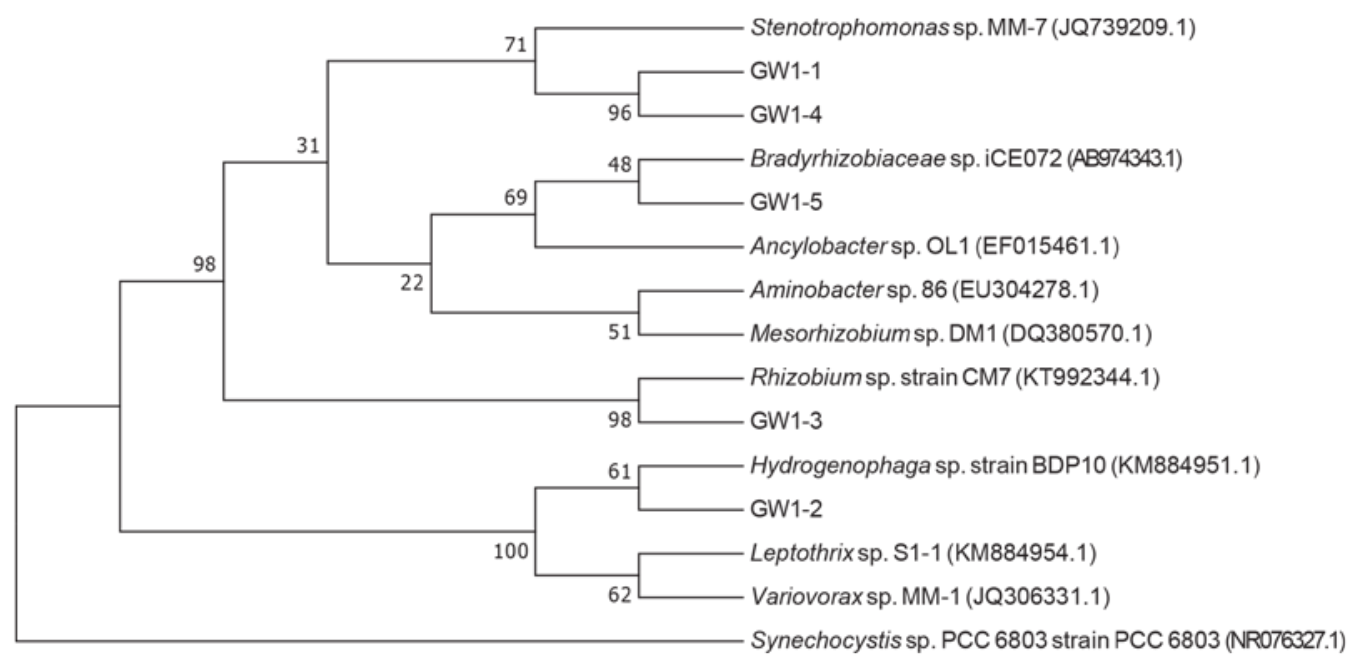

Fig. 1. aio $A$ gene based phylogenetic tree constructed by using the neighbor-joining model with 1000 bootstrap value.

\section{Acknowledgement}

We are thankful to the International Postgraduate Program in Hazardous Substance and Environmental Management (HSM), Chulalongkorn University for financial support. We also would like to thank a New Researcher Grant from Mahidol University for financial support. We express our sincere thanks to the Grant for International Research Integration: Chula Research Scholar, Ratchadaphiseksomphot Endowment Fund (GCURS-59-06-79-01), the Office of Higher Education Commission (OHEC) and the S\&T Postgraduate Education and Research Development Office (PERDO) for the financial support of the Research Program.

\section{References}

1. R. T. Lugtu, S. C. Choi and Y.S. Oh, J Microbiol, 47, 6, pp. 686-692 (2009)

2. P. L. Smedley and D. G. Kinniburgh, Applied Geochemistry, 17, 5, pp. 517-568 (2002)

3. D. Lievremont, P. N. Bertin and M. C. Lett, Biochimie, 91, 10, pp. 1229-1 (2009)

4. A. C. Kao, Y. J. Chu, F. L. Hsu and V. H. C. Liao, Journal of Contaminant Hydrology, 155 (supplement C), pp. 1-8 (2013)

5. S. Z. Abbas, M. Riaz, N. Ramzan, M. T. Zahid, F. R. Shakoori and M. Rafatullah, Brazilian Journal of Microbiology, 45, 4, pp. 1309-1315 (2014)

6. J. R. Lloyd and R. S. Oremland, Elements, 2, 2, pp. 85, (2006)

7. R. S. Oremland and J. F. Stolz, Trends Microbiol, 13, 2, pp.45-49, (2005)

8. M. Roy, A. K. Giri, S. Dutta, and P. Mukherjee, Environ Int, 75, pp. 180-198 (2015)

9. J. F. Ferguson and J.Gavis, Water Research, 6, 11, pp. 1259-1274 (1972)

10. S. Silver and L. T. Phung, Appl Environ Microbiol, 71, 2, pp. 599-608 (2005)

11. L. Cai, G. Liu, C. Rensing and G. Wang, BMC Microbiol, 9, 4, (2009)
12. C. Valenzuela, V. L. Campos, J. Yanez, C. A. Zaror and M. A. Mondaca, Bull Environ Contam Toxicol, 82, 5, pp. 593-596, (2009)

13. S. P. Bachate, R. M. Khapare and K. M. Kodam, Applied Microbiology and Biotechnology, 93, 5, pp. 2135-2145, (2012)

14. W. Weeger, D. Lièvremont, M. Perret, F. Lagarde, J. C. Hubert, M. Leroy and M. C. Lett, Biometals, 12, 2, pp. 141-149 (1999)

15. M. Quéméneur, A. Cébron, P. Billard, F. BattagliaBrunet, F. Garrido, C. Leyval and C. Joulian, Applied and Environmental Microbiology, 76, 13, pp. 4566-4570 (2010)

16. B. Vogelstein and D. Gillespie, Proceedings of the National Academy of Sciences of the United States of America, 76, 2, pp. 615-619 (1979)

17. S. Kumar, G. Stecher and K. Tamura, Mol Biol Evol, 33, 7, pp. 1870-1874 (2016)

18. K. F. Akter, G. Owens, D. E. Davey and R Naidu, Reviews of Environmental Contamination and Toxicology, 184, pp. 97-149 (2005)

19. S. Sadeg and N. Karahanoðlu, Environmental Geology, 40, 9, pp. 1151-1168 (2001)

20. K. Q. Xiao, L. G. Li, L. P. Ma, S. Y. Zhang, P. Bao, T. Zhang and Y. G. Zhu, Environmental Pollution, 211, pp.1-8 (2016)

21. J. M.Santini, L. I. Sly, R. D. Schnagl and J. M. Macy, Applied and Environmental Microbiology, 66, 1, pp. 92-97 (2000)

22. S. Tamaki and W. T. Frankenberger, Reviews of Environmental Contamination and Toxicology: Continuation of Residue Reviews, 124, pp. 79-110 (1992)

23. P. Li, Y. Wang, X. Dai, R Zhang, Z Jiang, D. Jiang, S.Wang, H. jiang, Y. Wang and H. Dong, PLoS ONE, 10, 5 (2015)

24. M. M. Bahar, M. Megharaj and R. Naidu, Biodegradation, 23, 6, pp. 803-812 (2012) 